\title{
From Prescription to Practice: The Evidence of Two Medical Papyri from Roman Egypt*
}

\author{
Isabella Andorlini
}

Papyri of medical content from Greco-Roman Egypt, either important literary texts or documents related to the daily life of country people in Egypt, have received increasing attention in classical scholarship during the last two decades of the $20^{\text {th }}$ century. That is due, at least in part, to the scholarly work of Louise Canberg Youtie, the expert papyrologist who worked hard in the legendary Papyrology Room 807 lastly housed in the Hatcher Library of the Michigan University at Ann Arbor. Thanks to the fact that she focused her high-quality research on the field of medical papyri since the end of the Seventies, Mrs Youtie was able to suggest to her colleagues, and to myself, who was just taking my first steps in papyrology, some encouraging possibilities for future research: (firstly) that thanks to a renewed philological and hermeneutic approach it was even possible to understand puzzling medical matters such as preserved by scattered papyrus fragments coming from the dry sands of Egypt; (secondly) that

* The text was presented by Isabella Andorlini on the occasion of the $2^{\text {nd }}$ Turner Colloquium at the Institute of Classical Studies \& University College, London, on May 31, 2005, and was based on a previous version read at the Duke University, Durham (NC), on November 22, 2002, during her research stay at Princeton. She started the latter with the following words: "First of all, I would like to thank Professor John Oates warmly for his kind invitation to Duke University. It is an honour for me, and a great pleasure as well, to give a talk in such an advanced center for Papyrology which has been able to provide formidable tools to scholarly research - and most recently the Duke Papyrus Archive and the Database of Documentary Papyri both available on the web", while the London speech was introduced by the Author's warm thanks to Cornelia Römer and Chris Carey for their invitation. Both texts are basically identical to each other, except for the following paragraph, added on occasion of the London Colloquium: "In a 1981 letter by Sir Eric Turner commenting my first scholarly work concerning the revision of some medical Aberdeen Papyri, Turner acknowledged the fact that 'we have at least three women - Mrs Youtie, Mrs Hanson, and now Ms Andorlini - who understand of medical papyri'. It is my pleasure today to resume his valuable encouragement participating into the Second Colloquium entitled to his leading figure". The text, previously unpublished, is presented here with slight updates in the framework of the project "Online Humanities Scholarship: A Digital Medical Library Based on Ancient Texts" (ERC-AdG-2013-DIGMEDTEXT, Grant Agreement no. 339828, Principal Investigator Prof. Isabella Andorlini) funded by the European Research Council at the University of Parma. [Editor's note] 
the close relationship of Greek medical papyri labeled 'anonymous' to the surviving ancient medical writings, both vernacular and canonical, enable us to locate fragments in a broader historical and cultural context; (thirdly) that the effort to provide refined re-editions of smaller fragments disdained, or cursorily transcribed, by earlier generations of scholars could reveal itself a very productive one, both for papyrologists and for historians of science.

Classicists and historians of ancient medicine can rejoice that, by comparison with the pioneering age of papyrological editions, students of medical texts are now well served by the dramatic increase of reference tools on this subject. ${ }^{1}$ Among others, I would mention (a) the review of published materials recorded in the Newsletter of The Society for Ancient Medicine started in 1986 by J. Scarborough, and lastly issued as Review by Ann Hanson in 1994-97; (b) the recent online catalogue of literary and sub-literary medical papyri kept up to date by Marie-Hélène Marganne at the Centre de Documentation de Papyrologie Littéraire of Liège; ${ }^{2}$ and last but not least, (c) the publications afforded so far within the editorial project "Corpus of Greek Medical Papyri" in which I am currently engaged, a project which proceeds with the cooperation of, and contributions from, an international team of scholars, ${ }^{3}$ and which has recently evolved in the "Digital Corpus of the Greek Medical Papyri", with the wider and path-breaking purpose of providing digital online critical editions of all published medical texts on papyrus, and awarded by an ERC Advanced Grant for the creation of the source files. ${ }^{4}$

The diversity of genres exhibited by literary and sub-literary medical papyri, ranging in date from the third century $\mathrm{BC}$ to the seventh century $\mathrm{AD}$, provides an idea of the vast quantity of material on ancient medicine that has been lost. They also greatly enrich our knowledge of the variety of Greek medical writings in wide circulation among the Greek or Greco-Egyptian literate readers.

Apart from the literary evidence displayed by medical books and handbooks copied by professional scribes, many suggestive bits of valuable information about the practice of medicine have been conveyed to us in respectable quantity through useful collections of drug recipes and single prescriptions. Yet the prescriptions are a varied lot, and they constitute a large majority of the 290 or more medical texts which have come down to us jotted on pieces of papyrus,

${ }^{1}$ Fundamental though now somehow outdated tools are of course still Marganne, Inventaire and Andorlini Marcone, Apporto. [Editor's note]

$2<$ http://web.philo.ulg.ac.be/cedopal>. Cf. Marganne/Mertens, Medici. [Editor's note]

${ }^{3}$ Cf. Andorlini, Progetto; Ead., Greek Medical Papyri I; Ead., Greek Medical Papyri II; Ead., Specimina; Ead., Testi medici. Under composition is Greek Medical Papyri III. [Editor's note]

${ }^{4}$ DIGMEDTEXT Project (2014-2016) as described at <http://www.papirologia.unipr.it/ERC $>$. The project is partner to the Digital Corpus of Literary Papyrology (DCLP). Bibliography: Andorlini/Reggiani, Edizione; Reggiani, Project; Id., Perspectives; Id., Digital Papyrology I, 2735; Andorlini, Piattaforma; Reggiani, Edition. [Editor's note] 
parchment or pottery. Let me emphasize that papyrus fragments are quite often badly preserved materials, written papers that have lost their beginning or ending and don't offer any firm clues about their nature. This is also a reason why any attempt to understand their content deserves tireless restoring cares and extensive investigations.

Through this very fragmentary framework, we learn nonetheless much about modes of medical thought and practice in Greco-Roman Egypt. Much of the evidence about doctors in Roman Egypt shows physicians in mundane contexts, such as tax-paying and personal transactions. Accordingly, only on rare occasions the evidence of documents such as private letters, medical reports addressed to public officials, or even orders of drugs for medicinal purposes affords a glimpse of doctors at work. Given their status of living texts, individual prescriptions as well are of exceptional interest on a number of counts: because they may have been commissioned by a practicing physician or compiled in detail by a pharmacist, they can give a fascinating sidelight onto the working methods of medical practitioners of ancient times.

Furthermore, through the pieces of evidence exhibited by medical prescriptions we may attempt to address several questions which continue to occupy those concerned with the stages of development of medical knowledge in the Mediterranean area, including the following:

- Which diseases were particularly prevalent in Egypt, and what were their standard treatments?

- How strictly can recipes found on the papyri be paralleled by similar texts of canonical medical writers who wrote in Greek or Latin during the Roman and Byzantine periods, distinguished authorities such as Dioscorides, Celsus, Galen, Oribasius, Aetius of Amida, and the like?

- How far is an individual recipe for a medicament able to preserve its textual integrity in spite of being excerpted and repeated from copy to copy, and in spite of being adapted by local practitioners to particular circumstances and situations?

- To what extent do the format and the content of recipes afford a veritable moving picture of doctor's activities and medical realia in Egypt?

- How do the prescriptions help to clarify the manufacture and trade of drugs for medicinal purposes in Roman Egypt? Moreover, what do recipes set down about the circulation and cost of drugs and spices of Egyptian and non-Egyptian origin?

Some of the problems I have adumbrated may be illustrated by means of a renewed consideration of the two medical papyri I am dealing with here. ${ }^{5}$ They

\footnotetext{
${ }^{5}$ During my stay of study at the IAS in Princeton 2002, I was able personally to re-examine the two originals in Princeton University's Firestone Library [P.Princ. III 155] and in the New York University collection located in the Bobst Library [P.New York xx.3]. I am most grateful to the staff of the Rare Book Collection of the Princeton University Library for making the papyrus available to me, and for providing me very quickly with excellent photographs.
} 
are both housed in North American collections and they are both practical texts of the Roman period, designed to serve the needs of physicians at work in their professional practice. Given their nature, these papyri were likely to appeal to the wider public of laymen who inhabited the provincial towns of Egypt, the peasantry of the country (the chora) seriously afflicted with body disorders.

Let us come to the first papyrus document. The Princeton papyrus labeled AM11224B, of unknown provenance and dated by the handwriting to the second/third century AD, was first published in 1942 by Allan Chester Johnson as "Accounts" in the third volume of the Papyri in the Princeton University Collections, number 155. In 1976, Louise Youtie first recognized the medical content of the texts written on both sides in the same hand, and published a revised edition of the recto side, ${ }^{6}$ announcing that the prescription on the other side would be "treated in a separate article." ${ }^{\prime 7}$ As she never managed to do so, I will now try to make good that promise, following Mrs Youtie's guidelines.

The edited Princeton papyrus 155 is a very small piece of papyrus, completely preserved and measuring only $3 \times 6 \mathrm{~cm}$. The papyrus itself was probably cut to this size to provide the surface on which the recipes were written ${ }^{8}$. Yet we have in front of us an intact sheet of papyrus, which is the exception rather than the rule in papyrus records unearthed in Egypt. Given the small size of the sheet, both texts are compressed and quickly written. Letters are linked together and deciphering the words may be complicated because of symbols and abbreviations; sometimes the word-ending is written in a long, wavering line. The small papyrus preserves, in fact, two medical prescriptions for eye-salves of a type common in medical literature. The recipes, complete with titles and directions for use, are ranged under very brief rubrics, such as statikon, "astringent", on the front, and paidikon, a remedy good "for children", on the back. Individual ingredients and their quantities are listed below the two entries, each ingredient occupying a single line in a one-column format.

Before providing text and translation of both the preserved texts, I would like to pinpoint some preliminary information: (a) firstly, that in the first edition by A. C. Johnson the recto and verso sides were interchanged. I now provide a translation of the two texts in the original copying order, that should have presumably been recto-side, first, and verso-side, later; (b) secondly, that the amounts of the ingredients are given in drachmas, each drachma, like the Roman

\footnotetext{
${ }^{6}$ Youtie, Prescription, with Pl. Xd. The re-edition has been included in the Sammelbuch as SB XIV 12086. Each side bears a medical recipe; they were regarded as lists of drugs with their prices by the ed.pr. See the online edition by Nicola Reggiani at <http://www.litpap.info/dclp/63920>. [Editor's note]

${ }^{7}$ Youtie, Prescription, 121 n. 2.

${ }^{8}$ For the possible use of such a small scrap of papyrus see Andorlini, Gergo, 47-8. [Editor's note]
} 
denarius, being counted as 6 obols, and equivalent to the weight of about 4 grammes; (c) thirdly, that the figures indicating the quantities are expressed as alphabetic letters preceded by the symbol for drachmas, a simple curving line (a serpentine).

The content of the text runs as follows: ${ }^{9}$

front side

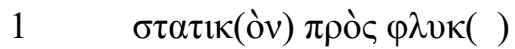

$2 \pi \varepsilon \pi \varepsilon \rho \varepsilon \omega \varsigma(\delta \rho \alpha \chi \mu \grave{\varsigma}) \beta$

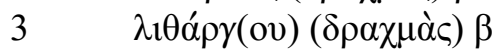

$4 \quad \zeta \mu v ́ \rho \eta \eta \varsigma(\delta \rho \alpha \chi \mu \grave{\varsigma}) \delta$

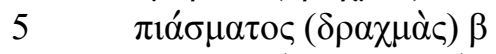

$6 \quad \kappa o ́ \mu \mu \varepsilon \omega \varsigma^{\prime}(\delta \rho \alpha \chi \mu \grave{\varsigma} \varsigma)$ i

7 ớvov $\chi \rho(\hat{\omega}) \tau$ 七ò $к \mu \mu \mu($ )

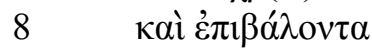

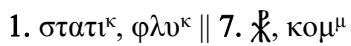

An eye-salve labeled 'stauncher' against blisters. Pepper 2 drs.; lead oxide (i.e. spuma argenti, litharge) 2 drs.; myrrh 4 drs.; pressed perfumed oil 2 drs.; gum of the acacia tree 10 drs. Use with wine; but add the gum, rubbing (levigate, emulsify the the gum to get the right thickness).

back side

$1 \pi \alpha 1 \delta 1 \kappa(o ́ v)$

$2 \quad \chi \alpha \lambda \kappa(\mathrm{ov}) \kappa \varepsilon \kappa \alpha v \mu(\varepsilon \dot{\varepsilon} v 0 v)(\delta \rho \alpha \chi \mu \grave{\varsigma} \varsigma) \delta$

$3 \kappa \alpha \delta \mu i_{\alpha \varsigma}(\delta \rho \alpha \chi \mu \grave{\varsigma}) \varsigma-\eta$

4 ỏ $\pi$ íov vacat $(\delta \rho \alpha \chi \mu \grave{\varsigma} \varsigma) \beta-\varsigma$

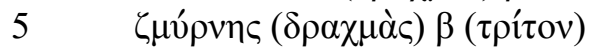

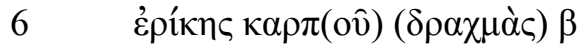

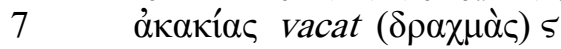

$8 \quad \kappa o ́ \mu \mu(\varepsilon \omega \varsigma)$ vacat $(\delta \rho \alpha \chi \mu \grave{\alpha} \varsigma) \varsigma$

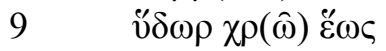

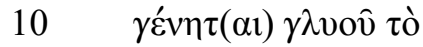

$11 \pi \alpha ́ \chi 0 \varsigma$

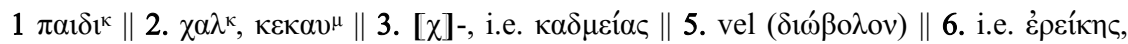

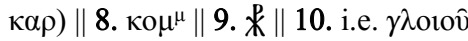

\footnotetext{
${ }^{9}$ A good high-resolution scalable image is available on the website of the Princeton library, at $<$ http://arks.princeton.edu/ark:/88435/0p096950c $>$. [Editor's note]
} 
An eye-salve labeled 'good for children'. Burnt copper 4 drs.; zinc oxide 6 or 8 drs.; poppy juice 2 or 6 drs.; myrrh 2 drs.; 2 obols; erica seed-pod 2 drs.; acacia 6 drs.; gum arabic 6 drs. Use with water until it achieves a glutinous consistency.

Some brief remarks limited to particular points may help clarify individual details of the re-examined texts.

In the front side, the Greek word for the title is $\sigma \tau \alpha \tau \iota \kappa o ́ v v^{10}(1.1)$ in the meaning of an "astringent" salve, a title frequently used for ointments, either with or

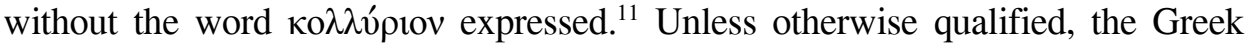

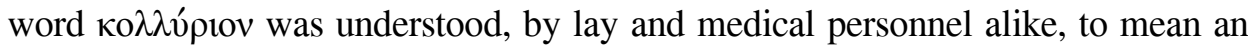
eye-medicine. The supplement to the last word of the first line is difficult. One possibility is to solve the abbreviation $\varphi \lambda v^{\kappa}$ (the reading $\varphi \lambda v \kappa()$ seems to me better than $\Phi \lambda \alpha($ ) ed.pr.) as $\varphi \lambda v \kappa \tau i \delta \alpha \varsigma$, or $\varphi \lambda v \kappa \tau \alpha i v \alpha \varsigma$, which were "blisters (or pustules, red swelling of the skin)", on the analogy of a similar recipe in Galen (XII 758,16 K., cf. XII 758,4; 765,15 K.), repeated by Oribasius and Aetius.

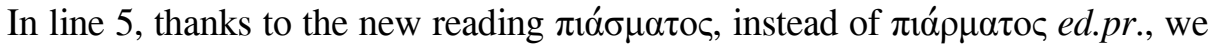
achieve a word which occurred only once in papyrus documents published so far, namely in a Florentine second-century papyrus of the "Società Italiana" (PSI IX

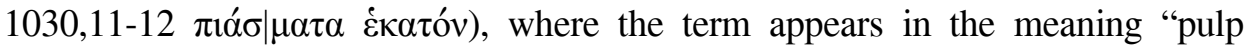
pressed out of the olives". $\pi \dot{i} \alpha \sigma \mu \alpha$ is the later Greek common spelling occurring in the papyri in place of the classical Greek $\pi^{i} \varepsilon \sigma \mu \alpha$, and it gives the suitable meaning of "anything pressed". That it really was, in this medical context, an aromatic oildrug pressed out of an 'acorn', the sweet fruit of a palm tree, the Balanites Aegyptiaca, is shown by Galen's On the Composition of Remedies According to Place (XII 489,14, 18 K.), and the similar recipe collections, as Galen only refers to a $\pi \dot{\varepsilon} \varepsilon \sigma \mu \alpha$ as a "sweet oil made from balanos", a drug which frequently appears in Greek pharmacology as Myrobalanos or Balanos myrepsica.

In line 7, olvov $\chi \rho(\hat{\omega})$ for olv $\chi \rho(\hat{\omega})$ "use with wine" is likely a variation influenced by the genitive endings of the preceding items in the list, becoming a sort of formula - completely detached from the syntactic context - comparable with the most common $v \delta \omega \rho \chi \rho(\widehat{\omega}) .{ }^{12}$ [Editor's note]

As regards the recipe on the back, the "children's" ко $\lambda \lambda$ v́ptov, the method of indicating alternative amounts (line 3: "6 or 8 drs. of zinc oxide"; line 4: "2 or 6 drs. of copper") is noteworthy, and indeed so far unique among the prescriptions preserved on papyrus. Since the ingredients, and their alternative quantities, are also found in the corresponding two recipes of Galen's book IV of his On the

\footnotetext{
${ }^{10}$ For the type of abbreviation cf. Andorlini, Gergo, 47. [Editor's note]

${ }^{11}$ For a general overview of the Greek terminology related to collyria cf. Kind, Kollurion; in

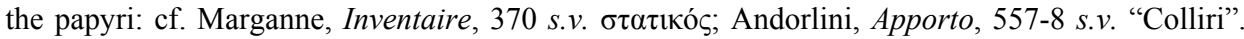
[Editor's note]

${ }^{12}$ Cf. Andorlini, Gergo, 161 and 163. [Editor's note]
} 
Composition of Remedies According to Place (XII 749-50; 761 K.), we may well believe that it was this book of Galen which was the direct source of the prescription preserved in P.Princ. III 155.

Most of the aromatic substances so far mentioned are also to be found in early $20^{\text {th }}$ century pharmaceutical guides. Even though synthetic drugs have mostly replaced these natural products, pharmacy nonetheless attributes some beneficial physiological action to the 'Eastern drugs' widespread in ancient times. Myrrh, for instance, is the famous oleo-gum-resin product Commiphora myrrha, native to Southern Arabia and North-Eastern Africa. Combined with the analgesic effect of the latex of opium poppy, it remains a favoured folk remedy for external sores or wounds. ${ }^{13}$ The property of pepper as a local stimulant is a fact widely recognized in ancient and modern pharmacopoeias. The pharmaceutical properties of gum arabic's constituents, including the akakia or kommi mentioned in the Princeton recipes, are verified in modern practice, since gum Arabic is an excellent tablet excipient, emulsifier and thickener. Conversely, although metal drugs were valued by Greco-Roman pharmacologists as drying agents in ophthalmic remedies, the poisoning effects of lead and copper compounds have been greatly recognized by medicine and pharmacy in medieval and modern times.

Both of the prescriptions exhibited by the Princeton papyrus are of the type commonly called acharista ("thankless") by Greek and Latin medical writers of all periods. ${ }^{14}$ Galen, writing in the second century, gives four; Oribasius, a fourth-century physician, has two; Aetius, a medical authority of the sixth century, also gives four. The first-century Latin writer Celsus provides us with one recipe, and Marcellus, also writing in Latin three centuries later, gives the same recipe with some changes. It was doubtless the common use of these ointments for an unpleasant affliction which gave them the name "thankless, ungrateful", in Latin id est sine gratia. Similarly, eye-salves of the achariston type are well attested by papyrus fragments of medical content of the Roman and Byzantine periods: let me recall a Grenfell papyrus [P.Grenf. I 52r/v], a fragment from the Tiflis collection [P.Ross.Georg. V 57v], a Berlin one [P.Berol. inv. $1944 \mathrm{v}=$ GMP I 13], and a papyrus scrap of the Louvre Museum in Paris [SN 144 = GMP I 14]. The wide circulation of this type of so-called "ungrateful" ointment strongly suggests that Galen was right to claim that the application of an achariston ointment was the standard first treatment in Egypt against 'ophthalmia', an eye-disease prevalent in Egypt and characterized by running eyes, swellings, and a thick rheum.

A relevant passage from Galen's work On the Composition of Remedies According to Places (IV $7=$ XII 749,13-15 K. ex Asclepiade) reports the

\footnotetext{
${ }^{13}$ On myrrh in the Greek medical prescriptions on papyrus cf. Andorlini, Ricette, 61-5. [Editor's note]

${ }^{14} \mathrm{Cf}$. Andorlini, P. Grenf., 6 ff. [Editor's note]
} 
following information closely related to our topic:

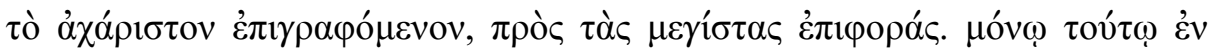

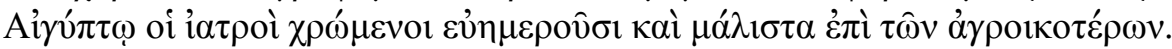

An eye-salve called achariston, good against eyes running seriously. By use of this remedy alone, the physicians in Egypt are successful (in treating the disease), especially among the country people.

On one side, this piece of evidence reveals that Galen, or his source, was rather complimentary about the success of the Egyptian doctors in treating the most troublesome diseases affecting the eyes. On the other side, both ancient and modern visitors to Egypt were, and still are, well conscious of the fact that eyediseases were, and still are, prevalent in Egypt, in part because of the very hot and dry climate, which has an unfortunate effect on the inhabitants. Still more widespread among peasant children, and often endemic as trachoma is, were the many infections of the eye and its margins. This fact helps to explain the existence in antiquity of special eye-salves designed for children (the paidikatype was certainly the more credited), and also acknowledges the achievements of local doctors in this particular field. Likewise, it is also possible to recognize in the ancient descriptions many ailments and infections which still occur today or have occurred in recent times.

Most of the acharista-recipes, like the $\pi \alpha 1 \delta$ เ óv of the Princeton papyrus, were limited in content to seven basic ingredients (zinc oxide [calamine], copper, acacia, erica fruit, opium, myrrh, and gum), ${ }^{15}$ but this was not always the case. Sometimes one or two of these ingredients might be omitted, or replaced by other components with similar properties. The formula is a common one: active mineral drugs (such as zinc, copper, or lead) are generally combined with aromatic ingredients (myrrh, or acacia, or erica fruit), all blended with an agglutinant, usually gum. The latter, according to the Latin writer Celsus, and other medical authors, ${ }^{16}$ and likewise according to the final directions of both prescriptions of the Princeton papyrus, was normally added last. This rule was especially advantageous in the manufacture of dried collyria, for it prevented them from crumbling.

So Celsus (VI 6,3) observes that when the salves made of gum (the Greek word kommi) have become dry, they stick together and do not break up (cummi cum quasdam alias facultates habeat, hoc maxime praestare, ut, ubi collyria facta inaruerunt, glutinata sint neque frientur). Accordingly, we have to

${ }^{15}$ Cf. Andorlini, P. Grenf.; Hanson, GMP I 13, pp. 150 ff. On kadmeia in the Greek medical prescriptions on papyrus cf. Andorlini, Ricette, 65-70. [Editor's note]

${ }^{16}$ Cels. VI 6,3; Paul.Aeg. VII 16,25. 
consider that this type of dried collyria recorded by prescriptions on papyrus were stored in a solid, stick form. ${ }^{17}$

Such a cocktail of antiseptic, astringent, caustic (the mineral ones), and anodyne substances (the poppy-tears) may well have proved beneficial in the prescribed treatment of eye diseases, though the combination of some ingredients (especially the caustic mineral drugs) may have caused unwelcome side-effects and may have been recorded as "unappreciated" (acharista!) by our very accurate sources.

To clarify how canonical recipes repeated from one medical writer to another could be excerpted by doctors in Egypt, and adapted with some variations to the particular needs of the country folk, I would like to point to the evidence of two outstanding passages drawn from literary and documentary sources.

In his extensive chapter on drug remedies for eye-diseases, in the sixth book, Celsus is much concerned with the possible purposes of variation in manufacturing an eye-salve. So he declares (VI 6,2):

multa autem multorumque auctorum collyria ad id apta sunt, nouisque etiam nunc mixturis temperari possunt, cum lenia medicamenta et modice reprimentia facile et uarie misceantur.

there are many salves devised by many inventors, and these can be blended even now in novel mixtures, for mild medicaments and moderate repressants may be readily and variously mingled.

The variation in the species and strength of herbal and mineral ingredients, and in their combination, is doubtless the reason for the proliferation of eye medicines, and for duplication of recipes in our written sources.

In a letter on papyrus dated to the second/third century $\mathrm{AD}$, an unknown writer is asking his father for a medicinal set he urgently needs in order to prepare two different remedies, presumably of the same nature, but opposite in strength. The pertinent distinction does not concerns the type of remedy, but rather the measure of its own aggressive power. It was probably due not to the properties of the ingredients, but to the relative degree of their power and effect. The writer of the letter says to his father (P.Oslo II 54,5-9):

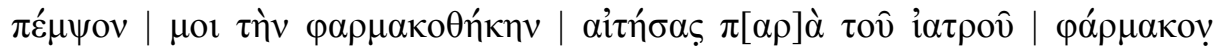

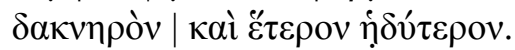

Please, send me the medicine box, as the doctor ordered a "very pungent"

${ }^{17}$ On which cf. Bonati, Contenere, 179, and Etichettatura, 47; on the same format - indicated with the same name - for incense, cf. Bonati, Incenso, 50. [Editor's note] 
remedy, and another "much gentler" ("a sweeter one").

Two similar options were perhaps offered to the user of the recipes transmitted together by the very small Princeton papyrus, and we are aware of the fact that in regard to remedies with the same purpose the most common option was between a 'soft' and a 'hard' treatment. The recipes follow a similar pattern, juxtaposing a $\sigma \tau \alpha \tau \iota \kappa o ́ v ~ t y p e$, which would have resulted in a 'milder' astringent by eliminating some mineral drugs, with the $\pi \alpha 1 \delta$ เón $v$ of greater strength, achieved through the aggressive power of copper and zinc.

Before turning to the next document, let us have a look again at the Princeton papyrus. If we compare the revised medical texts with the first edition by A. C. Johnson, we get proof of how extensively the texts of published papyrological editions change from time to time as they are worked on. All users of papyri should be on the alert to make improvements, and their proposals are more likely to be successful if verified on the original or on a good photograph. Such a happening is by no means unusual, even today. Yet it provides us with useful insights into some actual scholarly trends when considering a 'possible' medical content for papyri previously unpublished.

One reason is that critical method greatly benefits from the professional competence in a given field, as well as from the progress of technical aids. Another one is that when first transcribing a 'new' papyrus text a scholar makes hypotheses, in regard to both 'reading', and to 'interpreting' the nature of the text. To some extent an editor is also influenced by his own knowledge and by the trend of contemporary studies. We could assume with some confidence that the eye will see what it expects to see and that the mind will understand what it wants to understand. In light of these considerations, no wonder that an experienced scholar like A. C. Johnson, the main editor of the Princeton papyrus collection, who at that time was engaged in interpreting documents of the Roman period that are important for economic and social history, was moved to read what he expected to find in the "accounts" preserved by P.Princ. 155: the first entry on the front side was read by him as $\sigma \tau \alpha \tau i ́(v)$ (line 1), the equivalent of the Latin word statio, which implies a "military post" located in Roman Egypt; accordingly, Johnson was quite confident of interpreting the cross sign by the end of each prescription as the symbol "often used for the Roman denarius", that was the then current Roman coin. As is now clear from different pieces of evidence, such a combination of signs must be regarded as a particular symbol in a medical context. The Greek letter chi, crossed by the letter rho, is an abbreviation which occurs in medical prescriptions on papyrus. The sequence of

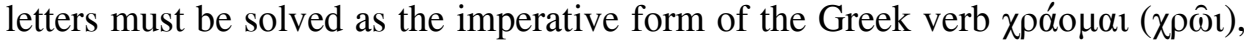
"to use", and regarded as the final formula of a recipe which suggests how an ointment should be mixed and applied. It may be useful to report that the Latin 
medical writers would have written recipe to give the same directions (the $2^{\text {nd }}$ sing. imper. of recipere, "to receive"), and the consequent abbreviation was long used by physicians to head their prescriptions. Besides, it should not be forgotten that the English word 'recipe', which is always applied to a set of doctor's instructions, is in fact derived from it!

Likewise, an equally risky trend in contemporary scholarship should be considered. The more a non specialist believes himself able to profit from the increase of medical papyrological tools, the more extravagant his assumptions about the nature of the text can become. Two recent examples can be given from my own experience. A piece of papyrus from the Milan collection was edited in 2000 by an expert scholar as a fragment of 'Materia medica', ${ }^{18}$ on the basis of scanty resemblances to a passage of Galen's work On Antidotes, ${ }^{19}$ as apparently suggested by computer-assisted searches. When worked on again for the catalogue of the Corpus of Greek Medical Papyri, the small scrap has been easily recognized, in fact, as a philosophical text transmitted by the late ancient anthologist Stobaeus, in the fifth century AD. Furthermore, a three-line Vienna papyrus published in 1997 as a "List of Medicinal Ingredients", ${ }^{20}$ and provided by the editor with extensive medico-historical comments and full bibliography, has revealed itself to be, in fact, an elementary list of fishes designed for the food-supply ${ }^{21}$.

The criticism I have applied to some modern editions of ancient medical texts strongly suggests the further methodological consideration that signs for numbers and metrological nomenclature of pharmacological texts are ambiguous, and not immune to alteration or inaccuracy. This appears to have been the case also for ancient medical evidence. ${ }^{22}$ Galen often mentions the problems presented by divergent copies of the same pharmacological text, which display discrepancies in their specifications of the quantities of individual ingredients. Problems with the accuracy of a pharmacological text especially arise when complicate equivalences occur between unit of measurement, dosage of each ingredient, and costs.

This point is well illustrated by a papyrus fragment of the New York collection, inventory number 468 (P.NewYork XX.3 = SB X 10492), first published 1966 by Naphtali Lewis in the first volume of the "American Studies in Papyrology" (pp. 4-6) = SB X 10492v. ${ }^{23}$

${ }^{18}$ P.Med. inv. 71.86f recto (I BC-I AD), ed. S. Daris = P.Bingen 3. The papyrus has been reexamined by Andorlini/Luiselli, Diotogene.

${ }^{19}$ De antidotis $\mathrm{II}=\mathrm{XIV} 120 ; 132 \mathrm{~K}$.

${ }^{20}$ P.Vindob. G 31787, ed. Sarischouli, Papyri, 37-42 („Liste mit Arzneimitteln“) = SB XXIV 16147. Corrections by Kramer, Urkundenreferat.

${ }^{21}$ Andorlini, Lista. [Editor's note]

${ }^{22}$ On this topic, see von Staden, Inefficacy.

${ }^{23}$ The text has been republished as P.NYU II 28 by Nielsen/Worp, New Papyri III, 136-8. [Editor's note] 
Copied in a rather small upright hand of the second/third century $\mathrm{AD}$, this list of recipes for plasters in two columns was recorded on the back of a document, a loan of money. In his edition, Lewis argued convincingly (a) that this was an account of expenditures for the ingredients of medicinal recipes, and (b) that it was likely to have been a private compilation for the needs of the user, rather than a compilation for reference. When he wrote his comments, more than 35 years ago, it was the only extant medical papyrus that included the cost of the ingredients. A singular text indeed, as we could count today only two more examples of this kind of record on papyrus (PSI inv. 1634; P.Worp 20).

The layout is the common one, consisting of title and enumeration of the ingredients with quantities given, and their costs. Quantities of solid ingredients are measured in drachmas, obols, and their fractions; when measuring liquid components, the recipes employ cotyls (ii 13, 22). The costs are expressed in drachmas. Although the interpretation was substantially correct, a few details concerning the titles of remedies and the calculation of costs remained unresolved in Lewis' edition. Given the fact that some of the figures for the costs appeared to make no sense, Lewis felt moved to attribute mistakes to the scribe when calculating the sub-total of lines 21-23, and the grand total of line 25 . Furthermore, Lewis assumed for this account a unit of seven obols to a drachma, instead of the more common six-obol drachma.

Thanks to some improvements made possible by my recent inspection of the papyrus, we may now establish (a) that the list of cols. i-ii contained a section designed for plasters with different titles (i 1: read $\pi \varepsilon \rho \grave{\varepsilon} \dot{\varepsilon} \mu \pi \lambda \alpha \dot{\sigma} \sigma \tau \rho \omega v$ ), all of them closely related to the tradition of medical authorities; and (b) that, according to a six-obol-drachma standard, the sub-total and grand total might, in fact, be correct as they appear in the papyrus. The heading $\dot{\alpha} \varphi \lambda \varepsilon \dot{\varepsilon} \gamma \mu \alpha v \tau o \varsigma$ (new reading, i 10) introduces a remedy generally effective against inflamed wounds, and is paralleled by several passages of Galen's book on the composition of poultices (Comp.med.gen. VII; according to Heras, XIII 547,9 K.; see also XIII

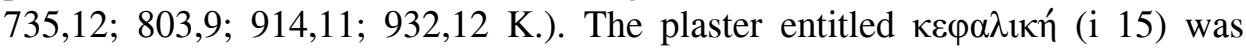

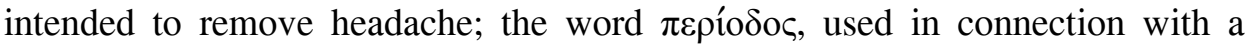
medicament (ii 20), might indicate a "regular circle" of applications.

Let us come to some concluding remarks in regard (1) to the format of the two papyri and (2) to their use in medical practice.

The small size exhibited by the Princeton papyrus is scantly documented within the thousands of records of the past which have come down to us from Egypt. A paper of this size, and written on both sides, would have been inappropriate for any standard mail delivery service, either in a private or in a public context. What ever could have been, then, the purpose of copying complete medical recipes on such small pieces of paper? Examples of documents in this size are the papyrus tags which were glued to the outside of 
rolls and carried a short title. Such tags were also used for titles of documents. These cases strongly suggest that very small sheets (like the medicinal labels called chartia which, according to Galen, On Antidotes XIV 79,7-11, circulated attached to small jars for spices) could have been attached to, or stored with, small containers of ointments and powders on the trade-market. ${ }^{24}$

Similarly, the New York list written on the back of a papyrus already employed for another purpose, strongly suggests that this was a private copy likely compiled by the small town drug seller, and designed for household use.

Once again, the evidence of the medical papyri, considered both as written evidence and as artifacts, provides an integrated view of theory and practice in a given field. Not surprisingly, all medical writers, Galen among them too, advocated that the doctor should know the ingredients of his own medicaments, and compound his drugs by himself. Indeed, medical writers were learned men, distinguished in their generations. ${ }^{25}$ Modern studies of the drug trade of antiquity, however, have frequently shed light on the humbler profession of the ancient drug sellers, and historians of medicine should lower their sights accordingly. Nonetheless, the accuracy of the data listed in the New York papyrus has just proved that a small town doctor in Egypt, and his patients, were absolutely right in putting their trust in the professional skill of the anonymous druggist who compiled the list of ingredients. This piece of evidence doesn't necessarily refute the model according to which "the universe of competent, qualified druggists is a merely hypothetical possibility," ${ }^{, 6}$ even if a papyrus fragment may perhaps strengthen this possibility.

\section{Bibliography}

Andorlini, Gergo = Isabella Andorlini, Il 'gergo' grafico ed espressivo della ricettazione medica antica, in: A. Marcone (ed.), Medicina e società nel mondo antico (Udine, 4-5 ottobre 2005), Firenze 2006, 142-67 = Ead., Scritti I, 15-36.

Andorlini, Greek Medical Papyri I = Isabella Andorlini (ed.), Greek Medical Papyri I, Firenze 2001.

Andorlini, Greek Medical Papyri II = Isabella Andorlini (ed.), Greek Medical Papyri II, Firenze 2009.

Andorlini, Lista = Isabella Andorlini, SB XXIV 16147 (P.Vindob. G 31787): lista alimentare, in: P.

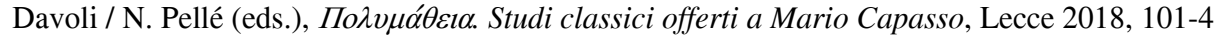
= Ead., Scritti II, 205-6.

Andorlini, $P$. Grenf. = Isabella Andorlini, $P$. Grenf. I 52: note farmacologiche, BASP 18 (1981), 1-25 = Ead., Scritti I, 49-68.

Andorlini, Piattaforma $=$ Isabella Andorlini, $I l$ corpus dei papiri medici online: la piattaforma

\footnotetext{
${ }^{24} \mathrm{Cf}$. Bonati, Contenere; Ead., Etichettatura.

${ }^{25}$ Cf. Hanson, Literacy; Ead., Doctor, in this volume.

${ }^{26}$ Kudlien, Schaustellerei.
} 
editoriale, in: A. Roselli (ed.), Atti del VII Colloquio Internazionale sull'Ecdotica dei testi medici greci (Procida, 11-13 giugno 2013), Napoli, forthcoming = Ead., Scritti I, 380-90.

Andorlini, Progetto = Isabella Andorlini, Progetto per il Corpus dei Papiri Greci di Medicina, in: B. Kramer / W. Luppe / H. Maehler / G. Poethke, Akten des 21. Internationalen Papyrologenkongresses (Berlin, 13-19 8. 1995), Berlin/Boston 1997, 17-24 = Ead., Scritti I, 337-43.

Andorlini, Ricette = Isabella Andorlini, Ricette mediche nei papiri: note d'interpretazione e analisi di ingredenti ( $\sigma \mu v \rho v \alpha, \kappa \alpha \delta \mu \varepsilon i ́ \alpha, \psi u v(\theta t o v)$, "Atti e Memorie dell'Accademia Toscana di Scienze e Lettere 'La Colombaria”" 46, n.s. 32 (1981), 33-81 = Ead., Scritti I, 37-48 + Scritti II, 63-80.

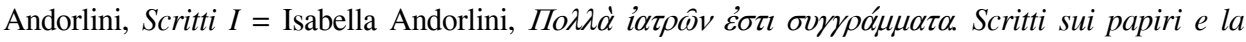
medicina antica, N. Reggiani (ed.), Firenze 2017.

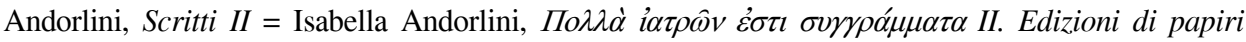
medici greci, N. Reggiani (ed.), Firenze 2018.

Andorlini, Specimina = Isabella Andorlini (ed.), 'Specimina' per il Corpus dei Papiri Greci di Medicina. Atti dell'incontro di studio (Firenze, 28-29 marzo 1996), Firenze 1997.

Andorlini, Testi = Isabella Andorlini (ed.), Testi medici su papiro. Atti dell'incontro di studio (Firenze, 3-4 giugno 2002), Firenze 2004.

Andorlini Marcone, Apporto = Isabella Andorlini Marcone, L'apporto dei papiri alla conoscenza della scienza medica antica, in: W. von Haase / H. Temporini (eds.), ANRW II 37.1, Berlin/New York 1993, 458-562.

Andorlini/Luiselli, Diotogene $=$ Isabella Andorlini / Raffaele Luiselli, Una ripresa di Diotogene Pitagorico, Sulla regalità, in PBingen 3 (encomio per Augusto?), ZPE 136 (2001), 155-66.

Andorlini/Reggiani, Edizione = Isabella Andorlini / Nicola Reggiani, Edizione e ricostruzione digitale dei testi papiracei, in N. Palazzolo (ed.), Diritto romano e scienze antichistiche nell'era digitale. Convegno di studio (Firenze, 12-13 settembre 2011), Torino 2012, 131-46 = Andorlini, Scritti I, 363-75.

Bonati, Contenere = Isabella Bonati, Contenere e siglare $i$ medicamenti: le ragioni di una storia, "Galenos" 8 (2014), 177-96.

Bonati, Etichettatura = Isabella Bonati, L'etichettatura del farmaco: radici antiche di una tradizione millenaria, in: Nicola Reggiani (ed.), Medica-papyrologica. Specimina di ricerca presentati al Convegno Internazionale "Parlare la Medicina" (Parma, 5-7 settembre 2016), Parma 2016, 43-77.

Bonati, Incenso = Isabella Bonati, Forme e contenitori di incenso nei papiri, "Papyrotheke" 1 (2010), 45-56 (URL: <http://www.dspace.unipr.it/ojs/index.php/Payrotheke/ article/view/5>).

Hanson, Doctor = Ann E. Hanson, The Greek Doctor in Ptolemaic, Roman, and Byzantine Egypt, in: N. Reggiani (ed.), Greek Medical Papyri: Text - Context - Hypertext. Proceedings of the Final DIGMETEXT Conference (Parma, 2-4 November 2016), Berlin/Boston 2019, 125-34.

Hanson, Literacy = Ann E. Hanson, Doctors' Literacy and Papyri of Medical Content, in: M. Horstmanshoff (ed.), Hippocrates and Medical Education, Leiden 2010, 187-204.

Kind, Kollurion = Emil Kind, Kollurion 1a, RE XI.1, 1921, 1100-6.

Kudlien, Schaustellerei $=$ Fridolf Kudlien, Schaustellerei und Heilmittelvertrieb in der Antike, "Gesnerus" 40 (1983), 91-8.

Kramer, Urkundenreferat = Bärbel Kramer, Urkundenreferat 1998, APF 45 (1999), 214-80.

Marganne, Inventaire = Marie-Hélène Marganne, Inventaire analytique des papyrus grecs de médecine, Genève 1981.

Marganne/Mertens, Medici = Marie-Hélène Marganne / Paul Mertens, Medici et Medica. $2 e$ édition (État au 15 janvier 1997 du fichier MP3 pour les papyrus médicaux littéraires), in: I. Andorlini (ed.), 'Specimina' per il Corpus dei Papiri Greci di Medicina, Firenze 1997, 3-71.

Nielsen/Worp, New Papyri III = Bruce E. Nielsen / Klaas A. Worp, New Papyri from the New York University Collection III, ZPE 140 (2002), 129-50. 
Reggiani, Digital Papyrology I = Nicola Reggiani, Digital Papyrology I, Berlin/New York 2017.

Reggiani, Edition = Nicola Reggiani, The Corpus of Greek Medical Papyri and the Digital Edition of Ancient Documents, in S. Torallas Tovar / A. Nodar (eds.), Proceedings of the 28th International Congress of Papyrology (Barcelona 2016), Barcelona, forthcoming.

Reggiani, Perspectives $=$ Nicola Reggiani, The Corpus of Greek Medical Papyri and Digital Papyrology: New Perspectives from an Ongoing Project, in: M. Berti / F. Naether (eds.), Altertumswissenschaften in a Digital Age: Egyptology, Papyrology and beyond. Proceedings of a Conference and Workshop in Leipzig (November 2015), Leipzig 2016, URL: <http://nbnresolving.de/urn:nbn:de:bsz:15-qucosa-201726>.

Reggiani, Project $=$ Nicola Reggiani, A Corpus of Literary Papyri Online: the Pilot Project of the Medical Texts via SoSOL, in R. Lafer / K. Strobel (eds.), Antike Lebenswelten Althistorische und papyrologische Studien, Berlin/New York 2015, 341-52.

Sarischouli, Papyri = Panagiota Sarischouli, Byzantinische Papyri aus der Wiener Papyrussammlung, "Papyri" 2 (1997), 35-48.

Von Staden, Inefficacy = Heinrich von Staden, Inefficacy, Error and Failure: Galen on dokima pharmaka aprakta, in: A. Debru (ed.), Galen on Pharmacology. Proceedings of the V International Galen Colloquium (Lille, 16-18 March 1995) (SAM 16), Leiden/Boston 1997, 59-83.

Youtie, Prescription = Louise C. Youtie, A Medical Prescription for an Eye-Salve (P. Princ. III 155 R), ZPE 23 (1976), 121-9. 
